\title{
ИСТОРИЯ ПОДОЛЬСКОЙ ДУХОВНОЙ СЕМИНАРИИ С МОМЕНТА ОСНОВАНИЯ В 1797 Г. ДО РЕФОРМЫ В 1817 Г.
}

\section{THE HISTORY OF THE PODOLSK THEOLOGICAL SEMINARY FROM THE MOMENT OF ITS FOUNDATION IN 1797 TO THE REFORM IN 1817}

V. Dzyubinsky

Summary: In order for the spiritual education of our time to occupy its welldeserved niche in the state, it is necessary to understand the experience of predecessors in the field of spiritual education. This understanding will make it possible not to repeat previously committed mistakes and will allow the modern system of Orthodox theological schools to develop in the right direction. In this paper, based on available printed sources, its been studied the fundamental factors of the Podolsk theological Seminary from its foundation in 1797 to its transfer from the town of Shargorod to the provincial city of Kamyanets in the Podolsk province. This is the time of educational institutions establishment, the settlement of the educational process, this is the period during which the Seminary became an educational center, forming the image of the Podolsk clergy. The article covers the background and the origin of religious education in the Podolsk region, the prerequisites for the Foundation of the Orthodox Seminary, the main difficulties that the administration had to face, the material side, sources of funding for the educational institution, the small number of teaching and administrative staff, the subjects studied, life and academic performance of Seminary students. This work fills a significant gap in the study of the history of Podolsk Seminary, conducting their activities in such a long period of time because attempts to give a complete picture of the history of the Seminary was not carried out, as well as its role in the entire system of spiritual education of the Russian Empire of the XIX century was not comprehended. The purpose of the article is to investigate the problems of Orthodox education in Podillya by the beginning of the XIX century.

Keywords: Podolsk Theological Seminary, Orthodox education, teachers, educational process.

\author{
Дзюбинский Владислав Аркадьевич \\ Иерей, Аспирант, Московская Духовная Академия, \\ 2. Сергиев Посад \\ wladmda@mail.ru
}

Аннотация: Для того, чтобы духовное образование нашего времени заняло в государстве свою заслуженную нишу, необходимо осмыслить опыт предшественников на ниве духовного образования. Это осмысление даст возможность не повторять ранее совершённых ошибок и позволит развиваться в нужном направлении современной системе православных духовных школ. В данной работе на основании доступных печатных источников проводится исследование основополагающих факторов деятельности Подольской духовной семинарии с момента ее основания в 1797 г. до её перевода из местечка Шаргород в губернский город Каменец Подольской губернии. Это время становления учебного заведения, урегулирования образовательного процесса, это период за который семинария стала образовательным центром, формирующим облик подольского духовенства. В статье освещена предыстория и зарождение духовного образования в Подольском крае, предпосылки основания православной семинарии, основные трудности, с которыми пришлось столкнуться администрации, изучены материальная сторона, источники финансирования учебного заведения, немногочисленный преподавательский и административный состав, изучаемые предметы, быт и успеваемость учеников семинарии. Данная работа заполняет значительный пробел в исследовании истории Подольской семинарии, осуществлявшей свою деятельность в столь большой промежуток времени, поскольку попыток дать цельную картину истории семинарии не осуществлялось, как и не осмысливалась её роль во всей системе духовного образования Российской империи XIX столетия. Цель статьи - исследовать проблемы православного образования в Подолье к началу XIX века.

Ключевые слова: Подольская духовная семинария, православное образование, преподаватели, учебный процесс.

ко приходило в себя после бушевавшей эпидемии чумы и город Шаргород был обложен караульными постами вплоть до 9 декабря 1798 года. Большое количество детей священников уже обучалось в униатских училищах, часть священников не могли себе позволить отправить ребёнка на учёбу из-за сложного материального положения. Помещение семинарии было тесным и ветхим, что также не позволяло набрать большое количество учеников. Некоторые священник не хотели отправлять своих сыновей учиться, так как сын был незаменимым помощником по хозяйству. Не взирая на все сложности, в первый год удалось собрать 130 учеников. Сначала 
были открыты два низших класса, так как удалось найти только два учителя. Это были Алексей Жильцов и Василий Голосов. Ректором был назначен настоятель Шаргородского монастыря архимандрит Гавриил. Выпускник Киевской духовной академии, он был проповедником при кафедре киевского митрополита и членом Киевской декастерии. С 1783 по 1794 в сане игумена был капеланом при Российском посольстве в Варшаве. В материальном положении семинария получала некоторую сумму и от монастыря, которая была очень кстати. Из 1000 р. ас., выделенных Синодом в 1798 году, семинария могла потратить только треть этих денег на жалование ректору, префекту, учителям, лекарю, бедным ученикам, на семинарское правление и служителям. Остальное перечислялось на постройку общежития для малоимущих учеников. Двое учителей семинарии получали ничтожно мало. Один получал 50 р. ас., а второй - 40 р. ас. в год. Несмотря на недостаток средств и достаточно медленное устройство семинарии, ежегодно в заведении возрастало количество учеников. Если в 1798 году учеников было 130, то в следующем их было уже 186, в 1800 г. - 475, в 1801 г. - 542, 1802 г. - 625, в 1803 г. - 647. Быстрый рост учеников приводил к увеличению количества классов. В 1799 году были открыты средний (инфима) и высший грамматический классы (сннтаксис), в 1800 г. появились классы поэзии и риторики, в 1800 г. - класс философии, и в 1804 г. был открыт богословский класс. Такое разделение на классы и названия были абсолютно такими же, как и в Киевской Духовной Академии.

В низших классах ученики разделялись по успеваемости на 3 разряда: сенаторы (отличники), populus (хорошисты) и infimus populus (неспособные ученики). Это деление было для того, чтобы пробудить дух соперничества и стимулировать учеников к учёбе. Но на деле получалось так, что этим насаждалось неприязненное отношение учеников друг к другу. Ученик, принадлежавший к разряду роpulus и понимавший, что он лучше учится, чем кто-нибудь из сенаторов, писал перевод с латинского языка на русский или наоборот и приписывал в конце «de loco Domini N.N.». Если ученик, вызвавший другого на состязание действительно написал лучше, то он занимал место сенатора, а проигравший спор терял своё место, опускался в ранге и переходил в разряд populous.

Из 647 учеников в 1803 году в классе риторики обучался 141 ученик, поэзию изучало 82 воспитанника, в высшем грамматическом классе числились 109 человек. В 1805 году в ПДС обучалось 700 учеников: 204 - в классе риторики, 76 - в классе поэзии, 98 - в высшем грамматическом классе. Стоит отметить, что воспитанники классов богословия и философии назывались студентами, а проформы, инфимы, синтаксиса, поэзии и риторики - учениками. В первые годы после открытия семинарии и резкого увеличения воспитанников возникла проблема острой нехватки учителей. К этому времени владыка
Иоанникий совершил личную поездку в Киевскую академию и пригласил оттуда учеников на преподавательские должности в семинарию, большинство из которых были родом с Подолья. К 1800 году владыке удалось испросить у Синода на содержание семинарии 3000 р. ас. В год (вместо прежних 1000 р.). В 1802 году семинария впервые отправила на свои средства двух лучших воспитанников риторического класса в Киевскую духовную академию для подготовки к преподавательской деятельности с дальнейшим возвращением на места учителей в ПДС. В 1803 году это были Сильвестр Гогоцкий и Григорий Левицкий, в 1808 г. были отправлены Григорий Александрович и Сильвестр Адиясевич, 1814 г. - Василий Романовский и Фома Татомирт [3.с.871, 4] В 1806 году состоялся первый выпуск воспитанников числом 55 человек.

В 1799 году, когда всё было готово, Преосвященный Иоанникий переехал вместе с епархиальной консисторией в губернский город Каменец. Ранее в Каменце вблизи Иоанно-Предтеченской церкви существовала униатская так называемая «Русская семинария», которую униатский епископ Пётр (Белянский) основал и построил на деньги униатского духовенства. В 1789 году он издал устав для своего духовенства, в котором было предписано, чтобы каждый священник ежегодно жертвовал по 7 польских злотых на содержание семинарии, епископской кафедры и дома для исправления опорочивших своё имя священников. К тому времени Иоанно-Предтеченский собор имел 22 тыс. польских злотых фундуша от имущества умерших во время эпидемии чумы священников, не оставивших наследников. К моменту перехода Каменца в 1793 г. под власть Российской короны, его фундуш увеличился до 100 тыс. польских злотых, благодаря пожертвованиям священников и личному вкладу епископа Петра в размере 36 тыс. злотых. После присоединения Подолья к Российской империи эта семинария была закрыта, а её здание конфисковано и передано в распоряжение Казённой Палаты. Эта внушительная сумма была передана по требованию Святейшего Синода в 1842 г. в Хозяйственное управление при Синоде. В этом достаточно просторном здании после конфискации с 1798 года располагался театр и редуты (танцевальные собрания). На него Преосвященный Иоанникий обратил внимание и добился передачи в духовное ведомство этого здания для устройства православной семинарии, несмотря на противление со стороны светских властей, особенно вице-губернатора Подольской губернии Сафоновича. [3, с.873, 4] После того, как всё было готово, владыка начал хлопотать перед Синодом о переводе своего детища из Шаргорода в Каменец. Основным его аргументом было неудобство в управлении семинарией из-за её географической отдаленности. В 1805 году здание было передано, а в следующем году сюда уже был перенесён из Шаргорода класс богословия и были открыты три низших класса для детей духовенства из бли- 
жайших к Каменцу уездов. В 1807 г. был перенесён класс поэзии, а ещё через год - класс философии. В 1808 г. также были открыты второй богословский курс и класс риторики, который существовал и в Шаргородской семинарии. Таким образом, в Подольской епархии действовали сразу две семинарии: Шаргородская, состоявшая из трёх низших классов, и полноценная Каменецкая, в которую принимались для дальнейшего обучения выпускники из Шаргорода. Каменецкой семинарией управлял напрямую ректор, Шаргородской - вице-ректор, а после 1811 года - префект. С 1808 года семинария в Шаргороде стала именоваться низшим отделением семинарии Каменецкой. Подольская духовная семинария была устроена по образцу Киевской Академии, хотя в последней преподавание велось намного пространнее, с большим числом изучаемых дисциплин.

Руководители семинарским образованием того времени старались устроить его похожим на иезуитские коллегиумы. Много времени и сил учеников тратилось на изучение латинского языка и латинских авторов. К сожалению, при изучении грамматической, логической и риторической сторон латыни, не обращалось никакого внимания на древнюю церковную литературу и изучение славянского языка. Заучивание наизусть латинских авторов не оставляло времени на разбор и критический подход к ним. На первом плане стояло изучение различных фигур речи для умения красноречиво выражаться, но никто давал ни времени, ни возможности юношам вы- рабатывать своё собственное критическое мышление. Впрочем, такой подход к образованию был традицией того времени в целом, поэтому вина непосредственно учебного заведения в этом вопросе не существенна.

Подольская семинария, несмотря на изложенные проблемы, всегда славилась своими учителями, которые старались как можно большему научить своих воспитанников, приучить к усидчивому труду, привить стремление к основательному познанию. Многие выходили из стен семинарии с глубоким знанием всеобщей истории, латинского, французского и немецкого языков, отличным знанием математики. Это доказывает тот факт, что в 1802 году на обучение в семинарию поступил сын молодого священника села Войтовец, Брацлавского уезда и отец Великого Русского писателя, Михаил Андреевич Достоевский. [2, с.41] Поступив в пятнадцатилетнем возрасте, парень «к наукам был препонятен» (тогда были ученики к наукам «понятные», «малопонятные» и «непонятные»), хорошо знал языки, прошёл низший и средний классы. В 1808 году Михаил Достоевский переехал вместе с семинарией в Каменец, оставив своего брата Льва в Шаргородской семинарии. Через год, в 1809 году, его, как одного из лучших учеников, епархиальное правление отправило в Московское отделение Императорской Медико-хирургической академии. [2, с. 42]

\section{Сокращения:}

ПДС - Подольская духовная семинария.

ЛИТЕРАТУРА

1. А.И. Историко-статистическое описание Подольской епархии // Подольские епархиальные ведомости. Каменец-Подольский, 1862. Неофициальная часть. №21, 22.

2. Сараскина Л. Достоевский. М., 2013.832 с.

3. Синицкий Д. Исторические сведения о Подольской духовной семинарии // Подольские епархиальные ведомости. Неофициальная часть. Каменец-Подольский, 1865. № 20. С.865-866; №21. С.909.

4. Сірополко С. Історія освіти в Україні / Степан Сірополко. К.: Наук. думка, 2001. 912 с. 